\title{
DIMENSI-DIMENSI MISTIK TAFSIR AL-MIZAN (Studi atas Pemikiran Thabathaba'i dalam Tafsir Al-Mizan)
}

\author{
Yusno Abdullah Otta, M.Ag \\ Institut Agama Islam Negeri Manado, Manado, Indonesia \\ yusno.abdullah@iain-manado.ac.id
}

\begin{abstract}
The multidimensional crisis has not yet shown that it will end even causing casualties, not only material victims, but also casualties and the threat of disintegration. So that the assumption and image of most people that Sufism as a teaching that focuses on individual piety and ritual is rejected. Because, Sufism should be an alternative answer to the problematic pluralist society and universal social change. Therefore the research will try to focus on the work of one of the influential figures of Thabathaba Sufism by examining the monumental work of al-Mizan. This research comes from primary and secondary data, the main source of course is al-Mizan's interpretation while indirect work is the work of others about Thabathaba $i$ thinking. The results of this study are Thabathaba'i who carry out the moderate life of Irfan Tasawuf. For him, spiritual life is not running away from life itself. This expression is addressed to those who practice Irfan radically and conservatively. This phenomenon is emphasized by Thabathaba'i to be reformed. Through some of his works, the interpretation of Al-Mizan, he opened his readers' insight while at the same time straightening out a sad understanding of various things, especially Irfan's life.
\end{abstract}

Keywords:Sufism, al-Mizan, Thabathaba i, 'Irfan, Moderate.

Abstrak.Krisis multidimensional belum juga menunjukkan akan berakhir bahkan telah menimbulkan korban, tidak saja korban material, tetapi juga korban jiwa serta ancaman disintegrasi. Sehingga anggapan dan image sebagian besar orang bahwa tasawuf sebagai sebuah ajaran yang menitikberatkan pada kesalehan individual dan ritual tertolak.Sebab, tasawuf seharusnya bisa menjadi jawaban alternatif atas problematika masyarakat yang pluralis dan perubahan sosial secara universal. Oleh karena itu penelitian akan coba fokus membahas karya salah seorang tokoh tasawuf berpengaruh Thabathaba'i dengan mengkaji karya monumentalnya al-Mizan. Penelitian ini bersumber dari data primer dan sekunder, sumber utama tentu tafsir al-Mizan sedangkan karya yang tidak langsung adalah karya orang lain tentang pemikiran Thabathaba i. Hasil dari penelitian ini adalah Thabathaba'i seorang yang menjalankan kehidupan Irfan Tasawuf yang moderat. Baginya, kehidupan spiritual bukannya melarikan diri dari kehidupan itu sendiri.Ungkapan ini ditujukan kepada mereka yang mempraktekkan Irfan secara radikal dan konservatif.Gejala ini yang ditekankan Thabathaba'i untuk direformasi. Melalui beberapa karyanya, tafsir Al-Mizan, dia membuka wawasan pembacanya sekaligus meluruskan pemahaman yang miris tentang berbagai hal, terutama kehidupan irfan.

Kata Kunci:Tasawuf, al-Mizan, Thabathaba i, 'Irfan, Moderat. 


\section{Pendahuluan}

Tafsir Al-Mizan merupakan karya terbesar Thabathaba`i. Karya monumental ini telah memberikan pengaruh yang cukup signifikan tidak saja dilingkungan Syiah, tetapi di dunia Sunni. Dalam dunia pemikiran Islam dewasa ini, hampir semua peneliti yang mengkaji tafsir hampir bisa dipastikan tidak akan meninggalkan karya tafsir ini dalam kajian mereka. ${ }^{1}$ tidak berlebihan kiranya jika karya ini dikategorikan, sperti yang diungkapkan oleh Moojem Momen, sebagai karya yang memiliki kualitas lebih baik dibanding karya lainnya dalam bidang yang sama. ${ }^{2}$ Tdiak jauh berbeda dengan penilaian diatas, Murthadha Muthahhari juga memberikan apresiasi yang sama. Murid Thabathaba'I ini menjustifikasi bahwa tulisan gurunya tersebut sebagai karya terbesar yang pernah ada sepanjang

1 Jalaluddin Rakhma, Tafsir Sufi alFatihah: Muqaddimah, Bandung: Remaja Rosda Karya, hlm. xxi.

2 Moojen Moomen, An Introduction to Syiah Islam: The History of Twelver Shi ism, United States: Yale University Press, hlm. 173. Bandingkan dengan karya tafsir Syiah lainnya, seperti karya Ali ibn Ibrahim al-Qummy dan Muhammad al-Ayashi dan al-Tibyan karya Syaikh al-Ta`ifa Muhammad al-Thusi, serta Majma al-Bayan fi al-tafsir Al-Quran karya Abi `Ali al-fadhl ibn al-Hasan al-Thabarsi. sejarah tafsir al-Quran. ${ }^{3}$ Lebih dari itu, dalam pandangan sebagian pakar bahwa dibutuhkan waktu 60 sampai 100 tahun sampai orang menyadari kebesaran karya tafsir ini. ${ }^{4}$

Berbagai penelitian tersebut menggambarkan bahwa karya tafsir ini memiliki keunikan dan kekhasan tersendiri dilihat dari segi metodologisnya.Penulis tafsir ini, Thabathaba'I, tidak hanya memakai satu metode saja dalam menafsirkan setiap ayat, namun juga menggunakan pendekatan filosofis dan sufistik.Kedua pendekatan tersebut kemudian didasarkan pada analisis bahasa dan sandaran riwa`iy.Metode Thabathaba'I berbeda dengan metode yang dipergunakan oleh penafsir sebelumnya.Para pendahulu Thabathaba'I, lebih sering, mendasarkan penafsiran mereka pra konsepsi teori dan teori-teori yang telah ada.Akibatnya, penafsiran sebuah ayat lebih menonjolkan pemikiran penafsirnya, dengan teori-teori yang ada, daripada maksud ayat tersebut. Dalam ungkapan lain, ayat lebih banyak

3 Lihat komentar Murtadah Muthahhari dalam Thabathaba'I, (1995), Shi'I, Manila: alHidaya.

4Lihat misalnya Abu al-Qasim Razzaqi, (1406), "an introduction to al-mizan", dalam altawhid, Vol. III, No. 2, Rabi` al-Tsani-Jumada alTsani, hlm. 10. 
dibicarakan ketimbang membicarakan dirinya sendiri. Hal ini bisa dilihat dan dicermati dalam komentar Thabathaba'I terhadap ayat-ayat yang memiliki kaitan dengan mistik dalam Islam.

Sebagai karya tafsir, kitab ini memiliki keistemewaan tersendiri, tidak saja ditinjau dari gaya penafsiran yang dipakai oleh penulisnya. Lebih dari itu, karya tafsir ini mengkaji berbagai dimensi dari suatu obyek.Kajian dimensi mistik menjadi pilihan untuk diteliti lebih lanjut dari karya masterpiece ini yang menggunakan beberapa pendekatan secara integratif dalam menafsirkan ayat.

\section{Pembahasan}

\section{Riwayat Hidup dan Pendidikan Thabathaba'i}

Thabathaba'i bernama lengkap: alSayyid $^{5}$ Muhammad Husain ibn aiSayyid Muhammad ibn Muhammad Husain ibn al-Mirza 'Ali Ashghar Syaikh al-Islam al-Thabathaba'i al-TabrTz alQadhi6. Mufasir kita ini dilahirkan di

\footnotetext{
${ }^{5}$ Gelar "Sayyid" merupakan panggilan terhormat dan sebagai indikator bahwa orang yang menyandangnya memiliki hubungan keturunan dengan Nabi Di Iran, terutama Ahl alBayl, gelar ini tidak sama dengan kata "Sayyid" dalam dunia Arab umumnya, terutama dari kalangan Sunni, yang disejajarkan dengan sebutan "Gentleman" atau "Mr" seperti di Barat Istilah ini dipergunakan secara ekslusif serta untuk kalangan tertentu saja.
} 44. kota Tabriz, Iran (Persia), ${ }^{7}$ dengan nama Muhammad Husain pada tanggal 29 Dzulhijjah. Dia datang dari rumpun keluarga ulama sekaligus akademisi yang sangat kuat memegang tradisi keilmuan yang selama empat belas generasi, telah melahirkan ulama-ulama Islam terkemuka, dalam berbagai disiplin ilmu. Ayahnya, Muhammad, merupakan salah seorang ulama terkenal, tidak saja di Tabriz tapi juga di berbagai daerah lainnya di Iran, pada masanya. Dia adalah keturunan seorang ulama besar; Mirza Ali Ashgar Syaikh alIslam yang dihormati sebagai salah seorang ulama terhormat di Tabriz.Sementara kakeknya, al-Sayyid Muhammad Husain, adalah salah seorang murid terbaik dari pengarang al-Jawahir dan Syaikh MusaKasyif alGitha. ${ }^{8}$ Bila diruntun sampai ke atas,

7 Penjelasan lebih komprehensif mengenai sejarah, etnograpi, bahasa dan dialek, literatur Persia modern serta perobahan nama dari Persia menjadi Iran bisa dilihat dalam, M Th. Houtsman, et al, (Eds,), (1987), First Encyclopaedia of Islam, Vol VI, Leiden: E J Brill, him 1038-1058 Artikel pertama ditulis oleh J.H. Kremes, "Historical and Ethnographical Survey"; yang kedua oleh H.W Bailey, "Language and Dialects"; dan ketiga ditulis oleh E Berthels, "Modern Persian Literature".

8 Wafat di Tabriz tahun $1294 \mathrm{H}$ dan dimakamkan di Najef dalam usia lebih dari 80 tahun Dia meninggalkan beberapa karya, diantaranya; kitab fiqh (Manhaj al-Rasyad fi Syarhi al-Irsyad, Mabahis al-'Ibadat), dan pembahasannya tentang ilmu Nahwu dibukukannya dalam 12 jilid buku. Lihat, 
nasab keluarganya bersambung hingga kepada 'Ali ibn Abi Thalib (a.s). ${ }^{9}$

Sayyid Husein Nasr
menggolongkan Thabathaba'i dalam kelompok ulama tradisional yang sangat responsif terhadap berbagai pemikiran kontemporer. Dalam dirinya, lanjut Nasr, menyatu sosok seorang "Syaikh"; karena keakrabannya atas ilmu-ilmu Islam klasik, sekaligus ilmuwan dengan kualifikasi di atas rata-rata 10 " Gelar "hakim" atau teosof, yang hanya dikenal di dunia SyT'ah, disandangnya karena penguasaannya secara sempurna atas berbagai aliran filsafat, baik Timur maupun Barat. Selain itu, dia juga menguasai dengan baik berbagai bidang esoteris, tanpa melupakan ilmu-ilmu Syari'at, eksoteris.Sehingga Tokoh kita

"Pengantar Dr Husain Mahfudz", dalam alKulayni, (1375), Ushul al-Kafi, Jilid I, Iran Mathba'ah Haydar, hlm 37.

9 Silsilah nasabnya secara lengkap bisa dilihat dalam Agha Barzak Thahrani, (1370), Thabaqat A'lam al-Syi'ah, Jilid I, Naiaf: al-Mathba'ah al-'Ilmiyah, hlm 645.

10Dalam konteks ini term "tradisional" tidak selalu berkonotasi negatif Tidak berlebihan kiranya term ini disandangkan kepada Thabathaba'i karena kemampuannya menguasai secara baik dan sempurna berbagai disiplin ilmu klasik. Lebih dari itu, dia bahkan mampu mengkombinasikan antara fiqh dan Tafsir Alquran dengan filsafat, serta antara teosofi dengan tasawuf Lihat Haidar Baqir, (peny), S H Nasr, "Tentang Penulis", dalam Thabathaba'i, (1993), Hikmah Islam.Cet IV, teri Bandung Mizan, hlm 7-8. ini tidak hanya dikenal sebagai seorang faqih, tapi juga sekaligus seorang Arif. ${ }^{11}$ Masa kecil Thabathaba'i dilewatinya dengan menjadi seorang piatu karena ditinggal wafat ibunya, ketika masih berumur lima tahun. Empat tahun kemudian kesempitan hidup semakin melingkarinya dengan menjadi yatim piatu, setelah ayah tercinta menyusul ibunya.Belum lagi dengan tidak adanya penghasilan tetap untuk menyangga kebutuhan hidup yang disertai dengan menjauhnya para sahabat dan teman kerabat.Sehingga dia merasakan hidupnya teralienasi dari lingkungannya sendiri.Situasiini semakin diperparah lagi dengan sejumlah kesulitan lainnya.Keadaan sosio-ekonomi yang melanda daerahnya sebagai imbas dari invasi Rusia. Namun, semua kesempitan hidup tersebut dijadikannya sebagai sarana untuk mempraktekkan kehidupan 'irfani-nya dengan cara melatih jiwa dan hatinya.

Sebagaimana para pemikir Islam lainnya, pendidikan masa kecil Thabathaba'i berlangsung secara tradisional. Dengan kata lain, dia harus

11 Lihat Sayyid Hosen Nasr, "Sang Alim dari Tabriz", dalam Thabathaba'i , (1993), Menyingkap Rahasia Al-Qur'an, terj A Malik Madaniy dan Hamim Ilyas, Bandung Mizan, him 5-8; Juga Thabathaba'i, (1989), Islamic ..op. cit. hlm 13-18. 
bersentuhan dengan ilmu-ilmu dasar yang merupakan basic ilmu. Di tanah kelahirannya, Tabriz, dia telah mempelajari Alquran dan berbagai kitab klasik mengenai kesusasteraan dan sejarah, seperti, Gulistan dan Bustun karya Sa'di, Nesab dan Akhlaq, Anvar-e Sohayli, Tarikh-e Mo'jam, dan Irsydd AlQur'an, al-Hisab, serta beberapa karya ulama lainnya, seperti Amir-e Nezam. ${ }^{12}$ Secara umum, perjalanan pendidikan Thabathaba'i tidak bisa dilepaskan dari tiga lokasi yang merupakan daur putaran sumber baginya untuk menimba ilmu. Ketiga tempat tersebut ialah kota kelahirannya, Tabriz, Universitas Syi'ah di Najaf dan terakhir di Universitas Qum di Qum.

Tanah kelahiran Thabathaba'i menjadi "sekolah" pertama baginya untuk mengenyam pendidikan.Walinya, yang diamanahi oleh ayahnya untuk mengurus segala keperluannya, mendatangkan seorang guru privat yang datang ke rumah. Proses belajar sistem privat ini dijalani Thabathaba'i selama enam tahun dari 1922 sampai 1928 Di kota ini pula, dia berkenalan dengan ilmu pengetahuan langsung dari keluarganya yang terkenal sebagai keluarga ulama, dan, secara tidak

12 Thabãthabã'i, Islamic ...ibid., hlm 13. langsung, dia belajar dari kaumnya yang merupakan komunitas yang akrab dengan berabagai pengetahuan.

Thabathaba'i mulai mengkaji berbagai buku klasik yang berisi tentang agama dan bahasa Arab sambil mempelajari ilmu-ilmu dasar yang diberikan oleh para gurunya.Kecuali itu, dia juga mulai mempelajari beberapa bidang ilmu seperti gramatika, sintaksis, retorika, fiqh, ushul flqh, logika dan filsafat serta, apa yang disebut olehnya sendiri, "spiritual science".13Proses belajar keseluruhan bidang ilmu tersebut ditekuninya dalam waktu selama tujuh tahun sejak tahun 1928, dan dia menamatkan semuanya pada tahun 1935. Pada tahun yang sama Thabathaba'i melanjutkan pelajarannya secara formal di universitas Syi'ah di kota Najaf, Irak.

Di Universitas ini, Najaf, Thabathaba'i meneruskan kajiannya dalam ilmu naqliyah, seperti syari'ah dan prinsip-prinsip jurisprudensi.Mata pelajaran ini merupakan materi wajib bagi setiap siswa di universitas ini. Dalam materi ini, khususnya ilmu fikih dan ushulnya, Thabathaba'i mempelajarinya di bawah bimbingan langsung dua orang Syaikh yang terkemuka masa itu; Syaikh Mirza 13Ibid, him. 14. 
Muhammad Husain Na'ini ${ }^{14}$ dan Syaikh

Muhammad Husain Isfahani ${ }^{15}$ Selain itu, Thabathaba'i juga mempelajari dan menekuni beberapa cabang ilmu uqliyah, seperti filsafat dan esoteris, sampai dia menguasai kedua cabang ilmu ini dengan sempurna.

Tanpa meninggalkan pelajarannya dalam berbagai bidang ilmu naqliyah dan aqliyah, baik filsafat maupun syari'at, Thabathaba'i juga memperdalam kajiannya tentangilmu-

${ }^{14}$ Dia adalah Syaikh Muhammad Husain al-Na'ini al-Gharwi ibn Mirza 'Abd al-Rahim Syaikh al-lslam. Dilahirkan di daerah Na'in pada tahun 1277 H Pernah belajar dari Mirza Muhammad Husain al-Syirazi di Samara Gurunya yang lain, ketika berada di Najaf, adalah Mulia Kadzim al-Khurasani, yang digantikannya setelah gurunya meninggal dunia Dalam hawzah-nya., di Najaf, banyak murid yang berkumpul di sana menimba ilmu darinya Dia menjadi marja' al-diniyyah sepeninggal alIshfahani yang kala itu memegang otoritas tersebut Semasa hidupnya dia menulis beberapa risalah, di antaranya; Risalah fi al-Khayral wa alMu'athat wa Bay' al-Fudhul, Risalah fi al-Tarlib, Risalah fi al-Ma'ani al-Harfiyah, dan lain sebagainya Lihat Muhsin al-Amin al-'Amiliy, A'yan op.cit., hlm 44 dan 258; juga Ali al-Awsiy, Thabathaba'i...op.cit., hlm. 47.

15Dia lebih dikenal dengan panggilan alKambani. Tokoh dengan nama lengkap Syaikh Muhammad Husain ibn al-Hajj Muhammad Hasan Mu'in al-Tijari al-lshfahani al-Najefi dilahirkan pada tanggal 2 Muharram 1296 H Dia adalah salah seorang ulama terkemuka dan filosof ulung serta guru filsafat dan ushul yang terkenal Karya-karya yang ditinggalkan antara lain Ushul, fiqh, dan filsafat serta berbagai syair, di antaranya; Nihayah al-Dirayah fi Hasyiyah alKifayah, Ushul al-Fiqh, dan Risalah 'Amaliyah Ushul-Muqallidin Syaikh meninggal pada tahun $1361 \mathrm{H}$ Lihat al-Thahrani, (1375), l'habaqat $A^{\prime}$ lam al-Syi'ah, Jilid 1, Najaf: al-Mathba'ah al'llmiyah, hlm 560. ilmu esoteris, spiritual atau 'Irfani, dengan menelaah berbagai karya filsafat klasik, diantaranya, al-Syifa karya Ibn Sina ${ }^{16}$ dan al-Asfar al- 'Arba'ah karya Sadr al-Din Syirazi ${ }^{17}$ serta Tamhid al-

16 Nama lengkapnya Abu 'Ali al-Husayni ibn 'Abd Allah ibn 'Ali ibn Sina, dengan nama panggilan Abu 'Ali atau, lebih terkenal dengan sebutan, Ibn Sina Tokoh yang digelari "Syaikh al-Rais" ini lahir pada tahun 370/980-428/1037 Sebagai filosof Muslim, dalam beberapa hal, Ibn Sina memiliki keunikan tersendiri di banding filosof Muslim abad pertengahan lainnya Kemampuannya dalam mengelaborasi dan mengkomparasikan filsafat Islam dengan pemikiran filsafat Yunani secara sistematis sampai sekarang masih menjadi referensi yang cukup relevan bagi para filosof Timur dan Barat Karyanya yang brilian!, al-Syifa, walaupun banyak berbicara tentang medis, namun tidak sedikit muatan filosofis yang dikandung karya monumental ini Karya ini hingga sekarang masih menjadi referensi signifikan bagi mereka yang mengkaji medis maupun filsafat Untuk riwayat hidup dan pemikirannya lihat M M Syarif, (ed), A History op. cit., Vol I, hlm. 480506, Juga lihat Shams lnati, "Ibn 'Sina", dalam S H Nasr dan Oliver Leaman, (Eds ), (1996), History of Islamic Philosophy, Part I, London \& New York Routledge, hlm 231-246.

17 Tokoh yang lebih dikenal dengan nama Mulia Sadra ini tahun kelahirannya tidak diketahui secara pasti Dari beberapa karyanya yang sempat dikumpulkan oleh Thabathaba'i , disimpulkan oleh S H Nasr bahwa Mulia Sadra lahir tahun $979 \mathrm{H} / 1571$ atau $980 \mathrm{H} / 1572$, di Syiraz, Iran Dan meninggal 1640 M, di Basrah, Irak Dia adalah seorang filosof-sufi, teosofi, dan tokoh mazhab Isyraqi yang memimpin renaissance kebudayaan Islam pada abad ke-I7. Kehadirannya sering dianggap sebagai bukti tidak adanya kemandekan perkembangan pemikiran filosofis di Dunia Islam, yang disebutsebut terjadi pada, paling sedikit, lima abad belakangan ini Di tangannya filsafat masih berkembang setelah ditinggalkan oleh Ibn Rusyd Dia pula yang membentuk Mazhab Hikmah Anggota kelompok ini yang mengadakan pengkajian secara intensif dan mendalam tentang filsafat dan pemikirannya yang dilakukan secara konstan dan kontinyu. Karyanya yang monumental dalam filsafat adalah Hikmah al-Muta ahyah fi al-Asfar al- 
Qawa'id karya Ibnu Turkah Karya-karya tersebut dipelajarinya di bawah bimbingan seorang filosof terkenal saat itu, yaitu Sayyid Husain al-Badkuba'i. ${ }^{18}$ Oleh guru filsafatnya, al-Badkuba'i Thabathaba'i dianjurkan untuk menekuni bidang studi matematika, agar dengan bantuan ilmu eksak tersebut dia mampu berpikir secara logis.Mengikuti saran gurunya tersebut, Thabathaba'i mempelajarinya dari seorang guru matematika yang terkenal pada masa itu dan ahli bidangnya, Sayyid Abu al-QasimKhwansari.19Dari

'Aqliyah al-Arha'ah, 9 jilid, Beirut Dar Ihya alTurats al-'Arabi, 1981. Karya ini dipandang sebagai buku filsafat terbesar, karena belum ada yang melampui kelebihan buku ini dalam materi yang sama Untuk riwayat hidup dan doktrinya lihat Fazlur Rahman, (1975), The Philosophy of Mulia Sadra (Sadr al-Din al-Syirazi), New York: State University Press, S H. Nasr, "Sadr al-Din alSylrazi dalam M M Syarif, (ed ), A History . op.cit., hlm 932-961.

18 Nama lengkapnya adalah al-Sayyid Husain ibn Ridha ibn Musa al-Husainiy alBadkuba'i Dia termasuk dalam deretan ulama SyT'ah dan filosof handal Dilahirkan di sebuah desa di daerah yang menjadi nama panggilannya, Badkuba (Baku) sekitar tahun 1293 H Selain menguasai dengan baik bermacam ilmu aqliyah, filsafat, dia juga dikenal sebagai seorang komentator ulung, atas materi yang sama. Pernah menjadi murid dari dua orang Syaikh terkemuka aliran Persia, yakni Sayyid Mirza Abu al-Hasan ibn Muhammad alThabathaba'i al-Husayni al-Ishfahani, yang dikenal dengan nama Jilwah dan Aqa' Ali ibn Maula 'Abd Allah al-Mudarris al-Zunuri alTabriz al-Thahrani Lihat, Ali al-Awsiy, Thabalhaba 7 ...op.cit., hlm 48.

19 Nama lengkapnya adalah Sayyid Abu al-Qasim Ja'far ibn MahmGd ibn Mahdi alMausawiy al-Khawansari dilahikan tahun 1313 H Seorang ahli matematika dan sastra Dia hijrah
Syaikh ini Thabathaba'i bukan hanya mempelajari semua daur matematika tradisional, bahkan dia juga menekuni teori ilmu ukur bidang dan ruang serta bagaimana melakukan penalaran secara analitis. ${ }^{20}$

Masa belajar Thabathaba'i di Najaf memakan waktu hampir sepuluh tahun lamanya.Selama kurun waktu tersebut, dia menggali semua sumber ilmu pengetahuan.Sehingga, dia menguasainya dengan baik dan sempurna semua ilmu tersebut, mulai dari fiqh sampai tasawuf atau 'irfani dan matematika sampai filsafat. ${ }^{21}$

Selain mempelajari semua cabangcabang ilmu tersebut di atas, di universitas ini pula, Thabathaba'i berkenalan dengan berbagai ilmu, yang hanya diperoleh melalui hudhuri, ${ }^{22}$ atau

dari kampung halamannya menuju kota Najaf pada tahun 1328 H Di kota ini, Najaf, dia belajar fiqh, ushul fiqh dan hadis serta memperdalam ilmu matematika. Setelah itu dia berkelana ke India dan mengajar beberapa orang di sana dalam bidang hukum Sebagian besar karyanya tentang ilmu matematika ditulis dalam bahasa Persia Lihat Umar Ridha Kahalah, (1957), Mu 'jam al-Mu'allifin, Jilid 3, Damaskus: Mathba'ah al-Tarqi, hlm 150.

20 Lihat S.H Nasr, "Tentang Penulis", op.cit., hlm 9, Thabathaba'i, Islamic...op.cit., hlm 14; idem, Shi'a op.cit., hlm 22; Ali Awsiy, Thabathaba'i ...op.cit, hlm. 43.

21 Lihat Thabathabã'i, (t.th ), al-Syí'ah fi al-lslam, Teheran: t.p hlm. 24.

22 Mengenai bentuk ilmu ini, penulis akan mendiskusikannya lebih lanjut dalam tesis ini, terutama bab 3. 
ma 'rifat.Suatu pengetahuan yang bisa diperoleh lewat "kehadiran" yang menjelma menjadi penampakkan tentang hakikat-hakikat yang bersifat supranatural dan adikodrati.Dalam bidang ini, seperti yang digambarkan oleh Nasr, Thabathaba'i beruntung menemukan syaikh besar ma 'rifat, pada masa itu, Mirza 'Ali Qadhi.

Di bawah bimbingan 'Ali Qadhi, Thabathaba'i mengarungi rahasiarahasia Ilahi.Dia mengembara menuju kesempurnaan spiritual.Dalam bimbingan Syaikh ini pula, Thabathaba'i memahami dengan benar karya Ibn 'Arabi yang sangat terkenal yakni Fushus al-Hikam.Suatu karya yang dianggap oleh Thabathaba'i sudah dikuasainya dengan baik, namun sebenarnya belum. S.H. Nasr menggambarkan hal ini dengan: "AllamahThabathaba'i pernah berkata kepada saya bahwa sebelum bertemu dengan Mirza Qadhi, ia telah memperlajari Fushus al-Hikam dan mengira telah benar-benar memahaminya.Namun ketika bertemu dengan Syaikh besar ini, ia baru sadar bahwa sebenarnya ia belum tahu apaapa." 23 Tentang karya tersebut, Fushus al-Hikam, "Ia (Thabathaba'i ) juga 23 Sayyid HusenNasr, "Tentang Penulis",op.cit., hlm 9-10. bercerita kepada saya", lanjut Husein Nasr, "bahwa ketika Mirza Qadhi mulai mengajarkanFushus, seakan-akan dinding-dinding ruangan berbicara tentang hakikat ma'rifat (yang terkandung di dalamnya) dan ikut menguraikannya."24

Dalam pengawasan langsung Sang Syaikh, kehidupannya, selama beberapa tahun di Najaf, tidak hanya menjadi waktu untuk pencapaian intelektualrasional per se. Melainkan juga untuk meraih kezuhudan dan menyelami berbagai praktek spiritual yang menjadikannya mampu mencapai "keadaan realisasi spiritual" atau tajrid.25Kehidupan sufi dijalaninya dengan cara menghabiskan hari-harinya berpuasa. Sambil mengoptimalkan kualitas ibadah ini, Thabathaba'i juga menjalankan puasa bicara total dalam jangka waktu tertentu. Selain itu, dia tidak pernah berhenti merenung dengan penuh khidmat dan dalam konsentrasi sempurna, tentang berbagai hal, terutama yang berkaitan dengan masalah spiritual.Bahkan ketika sedang berbicara sekalipun. Sehingga,

\section{${ }^{24}$ Ibid , hlm. 10.}

${ }^{25}$ Tajrid atau tajarrud adalah suatu keadaan terlepasnya diri dan jiwa dari kegelapan batasan-batasan yang sifatnya material menuju pada penyatuan dengan Tuhan Kata ini bisa diidentikkan dengan ittihad.. 
kehadirannya, pada setiap kesempatan, membawa angin segar dan memberikan suatu pencerahan bagi mereka yang berada disekelilingnya.

Namun, kondisi seperti ini dirasakan oleh Thabathaba'i sedikit berubah ketika dia kembali ke tanah leluhurnya, Tabriz, pada tahun 1934, karena faktor ekonomi. ${ }^{26} \mathrm{Di}$ tanahkelahirannya ini dia merasakan kehidupannya meaningless, seperti yang digambarkannya sendiri sebagai "masa kekeringan ruhani dalam kehidupan saya". ${ }^{27}$ Kehidupan demikian tidak bisa dielakkan olehnya.Karena, di samping membuka lahan garapan (bertani) untuk menopang kebutuhan hidupnya sehari-hari, dia juga mengikuti berbagai kegiatan yang membutuhkan peningkatan intensitas kontak sosial.Kondisi seperti ini, kiranya, menjadi salah satu alasan baginya untuk berbuat demikian.Sehingga, dia merasa "kehilangan" waktu untuk mengasah intelektualnya dan menekuni kontemplasi, yang sudah menjadi bagian dari hidupnya ketika berada di Najaf. ${ }^{28}$

${ }^{26}$ S.H Nasr, "Preaface" dalam Thabathaba'i, Shi'a... op.cit.,hlm 23.

27Thabathabã i , Islamic...op.cit., hlm 15. 28 ibid.
Pola hidup seperti ini dirasakan dan dijalani Thabathaba'i selama hampir sepuluh tahun.Walau demikian, dia tetap berusaha, semampunya, untuk tetap berada dalam kehidupan spiritual serta tidak meninggalkan kecintaannya pada ilmu pengetahuan. Di balik segala kesulitan dan kesibukannya serta berada dalam dua sisi kehidupan; berbagai kontak sosial dan menjalani kehidupan asketis, tidak menjadikannya lupa akan kedua dimensi, yang disebut terakhir, di atas. Hal ini terlihat ketika dia masih menyisakan waktunya, di sela-sela kesibukannya, untuk mengajar beberapa pelajaran pada sekelompok kecil anak-anak di kotanya, sekembalinya dia dari Najaf.Meski begitu, namanya belum dikenal luas. Tetapi, semua itu berubah ketika dia harus pindah dari kota kelahirannya.

\section{Karir Intelektual Thabathaba'i}

Adanya agresi Uni Sovet atas Iran yang mengharuskan Thabathaba'i untuk pindah dari kota kelahirannya, Tabriz, ke kota suci Qum. Sehingga kepindahannya ini lebih bernuansa sosial-politik ketimbang intelektual.Namun demikian, karir intelektualThabathaba'i bukan dimulai di Qum, tetapi di tanah kelahirannya, Tabriz.Di Universitas Qum ini 
Thabathaba'i mengalami masa cemerlang dalam karir intelektualnya.

Thabathaba'i mulai dikenal orang secara luas, terutama mereka yang datang dari kalangan akademis. Karena di kota suci ini, sepertinya, dia menemukan lingkungan yang kondusif sebagai seorang 'arif sekaligus ilmuwan. Suatu keadaan dan situasi yang belum ditemuinya tatkala berada di Tabriz.Dia bersentuhan dengan para ulama dari seluruh Iran, bahkan dunia, dengan latar belakang pendidikan yang beragam dan disiplin ilmu yang berbeda, di antaranya Prof. Henry Corbin dan Kenneth Morgan. ${ }^{29}$

Thabathaba'i adalah tokoh yang memiliki daya tarik tersendiri bagi para civitas akademika universitas Qum dan masyarakat Iran secara umum. Karena, tidak berapa lama setelah keberadaannya di Qum, dia telah menjadi pusat perhatian semua kalangan. Sosok dan kepribadiannya yang calm and pleasant man, ${ }^{30}$ langsung memikat dan menjadi perhatian para mahasiswa.Dia senantiasa berkomunikasi dengan siapa

${ }^{29}$ Penulis buku Islam, the Straight Path Buku ini telah diterjemahkan dengan judul Islam Jalan Lurus, diterbitkan oleh Pustaka Jaya.

30 Penilaian Syaikh Ibrahim Amini, sarjana Muslim dan menulis banyak buku Lihat bagian akhir dari buku Thabathaba'i, Shi'a op.cit.
saja.Artinya, dia bisa berkomunikasi dengan baik dengan berbagai kalangan dari jenjang dan latar belakang pendidikan yang berbeda.Keluwesan dan kesederhanaannya ini merupakan, salah satu, apresiasi dari dimensi spiritual yang dimilikinya.

Tafsir, filsafat, dan teosofi tradisional merupakan mata pelajaran utama yang diampu Thabathaba'i ketika tiba di universitas Qum.Padahal, bidangbidang pelajaran ini tidak pernah lagi diajarkan di Universitas ini sebelumnya.Langkah ini diambil Thabathaba'i adalah untuk menekankan bahwa, selain ketiga materi tersebut telah dikuasainya dengan sempurna, semua bidang ilmu itu merupakan materi fundamen yangmesti dikuasai oleh setiap mahasiswa, sebelum menekuni bidang lainnya.Dalam bidang 'irfani dan filsafat, secara gradual, Thabathaba'i menerapkan ajaran-ajaran Mulia Shadra sebagai inti kurikulum tradisional. ${ }^{31}$

Di setiap pengajiannya, dia selalu berhadapan dengan sekitar empat ratus orang mahasiswa, yang meneguk setiap hikmah darinya.Mereka yang mendengarkan pelajaran darinya bisa dibagi dalam tiga kelompok

31S.H Nasr, "Tentang Penulis" dalam Thabathaba'i, Hikmah...op. cit., hlm 11. 
besar.Kelompok pertama adalah kaum tradisionalis di Qum.Kedua adalah mereka yang telah mendapatkan pengajaran dan gambaran tentang ma'rifat dan tasawuf.Kelompok ini dalam setiap pertemuannya duduk melingkar.Pertemuan kelompok ini diadakan pada setiap hari Kamis malam di rumahnya atau di salah satu rumah anggota kelompok ini.Dan terakhir adalah orang Persia atau non-Persia yang telah mengecap pendidikan modern yang ditemuinya, atau yang ingin belajar kepadanya, baik yang berada di Qum atau daerah lainnya, di Teheran. ${ }^{32}$

Ketika ajaran materialisme Marxis menjadi trend di kalangan sebagian pemuda di Qum, karena bias dari agresi Rusia atas Iran, Thabathaba'i adalah salah seorang ulama yang tampil mencurahkan perhatian khusus untuk mempelajari dasar filosofis ajaran komunis tersebut. Dalam tanggapannya atas ajaran-ajaran tersebut dia membela realisme, dari sudut pandang tradisional abad pertengahan, atas ajaran materialisme dialektika. Pemikirannya tentang hal ini dituangkanya dalam bukunya Ushul-i Falsafah wa Rawish ibid.
Ri'lism (Prinsip-prinsip Falsafah dan Metode Realisme). ${ }^{33}$

Selama berada di Qum, kegiatan ilmiah Thabathaba'i dapat dikelompokkan dalam empat bagian.

Pertama, menghidupkan kembali apa yang disebutnya dengan ilmu-ilmu aqliyah yang telah kering akibat lamanya rentang waktu saat ilmu tersebut muncul hinggaberkembang sampai masa Thabathaba'i. Di antara ilmu tersebut adalah 'Ulum Al-Qur'an sekaligus tafsirnya.Demikian pula dengan filsafat dan ilmu kalam.Untuk mengajarkan kedua materi tersebut, Thabathaba'i menetapkan bahan pokok yang dapat dijadikan patokan dalam mempelajari kembali ilmu tersebut.Kitab Al-Syifa karya ibn Sina dan karya Mulia Sadra, Al-Asfar adalah karya yang dijadikan pilihan utama Thabathaba'i sebagai referensi untuk kedua materi tersebut.

Kedua, memberikan pengaruh kepada masyarakat dalam pemikiran dan akhlak, dengan cara melihat kemampuan audiences.Hal ini dilakukannya pada setiap kesempatan memberikan pelajaran, baik dalam pertemuan resmi atau tidak.Usahanya ini disertai dan ditunjang dengan sikap dan kepribadiannya yang sarat dengan

\footnotetext{
33 S H Nasr, "Tentang op.cit.,hlm, 11.
} 
dimensi spiritual.Sikap ini memberikan kesan mendalam bagi siapa saja yang bertemu dengannya, meskipun mereka baru pertama kali berjumpa dengannya.

Ketiga, memberikan bimbingan kepada mereka yang telah mapan dalam berpikir tentang filsafat dan ilmu kalam. Metode pembelajaran ini dilakukan dengan cara berdiskusi. Anggota kelompok ini datang dari berbagai tempat serta dengan latar belakang pendidikan yang berbeda dan pemahaman yang beragam dalam masalah agama dan filsafat.Bahkan, tidak jarang Thabathaba'i berdiskusi dengan para tokoh agama lain, seperti Kristen dan Yahudi, serta tokoh agama lainnya.

Keempat, menulis berbagai buku dan artikel lainnya, baik berbahasa Arab maupun Persia, sebagai wujud tanggung jawab akademis.Sebagian besar buku yang ditulis oleh Thabathaba'i, dan umumnya para cerdik pandai Syi'ah, menggunakan bahasa yanga bisa dimengerti oleh semua pihak, baik masyarakat umum maupun akademisi. ${ }^{34}$ Dengan maksud agar tulisan-tulisan tersebut bisa dicerna dengan baik oleh pembaca yang hlm 51-52. memiliki latar belakang pendidikan yang berbeda.

Sepanjang karir intelektualnya, Thabathaba i telah menghasilkan beberapa karya dalam interdisipliner ilmu, seperti fiqh dan ushulnya, filsafat, tafsir, kalam, serta berbagai komentar atas beberapa karya klasik.Dari semua karyanya, Al-Mizan fi Tafsir Al-Qur'an merupakan karya yang paling monumental dan excellent ${ }^{35}$ Karya ini dirampungkannya ketika dia berada di Qum. Di kota ini pula dia melahirkan sebagian besar karyanya. Walaupun usaha tersebut telah dimulainya sejak berada di Najaf, Irak, dan kampung halamannya, Tabriz.

Seperti telah disebutkan sebelumnya, Thabathaba'i dikelilingi oleh sekitar empat ratus orang murid pada setiap pengajiannya.Ada sebagian dari murid-muridnya ini yang mengikuti langkah intelektualnya. Di antara mereka, seperti, Sayyid Jalai al-Din

\footnotetext{
35 Informasi yang bisa dilacak penulis, jumlah karya Thabathaba'i , seperti yang ditulisnya sendiri, berjumlah 38 buah Informasi senada juga diberikan oleh Ali Awsiy Semua karya ini, menurut Thabathaba'i , ditulis di berbagai tempat, seperti Najaf, Tabris dan Qum Dari semua karya itu sebanyak 19 buah ditulis dalam bahasa Arab dan sisanya berbahasa Persia Sekarang ini, para mahasiswanya, ketika berada di universitas Qum, yang mulai menerjemahkannya ke dalam bahasa Arab maupun Inggris Untuk daftar karyanya, lihat Thabathaba'i , Islamic op.cit., hlm 16-17; juga Ali Awsiy, Thabathaba'i ...op.cit., hlm 53-56.
} 
Ashtiyani, Murthadha Muthahhari (w. 1979), Sayyed Hosen Nasr, Sayyid Husein Khosrowshahi, dan William C. Chittick serta D. Shayegan. ${ }^{36}$

Di luar itu semua, satu hal yang harus diakui, bahwa Thabathaba'i , walaupun hidup di era modern, seperti yang diutarakan S.H. Nasr, tak memiliki kesadaran, secara langsung, apa yang disebut dengan mentalitas dan sifat dunia modern, yang mungkin diperlukan. Namun, adalah suatu hal yang tidak mungkin, mengharapkan keadaan seperti itu datang dari seseorang yang pengalaman hidupnya terbatas pada daur lingkaran Persia, Tabriz dan Qum, serta Irak, Najaf saja.

\section{Sketsa Tafsir Al-Mizan}

a. Waktu, Tempat dan Latar Belakang Penulisan

Tafsir ilmiah ini ${ }^{37}$ ditulis Thabathaba'i selama hampir dalam seluruh hidupnya.Penulisnya menamakan karya ini dengan AI-Mizan fi Tafsir al-Qur'an Tafsir ini dicetak dalam dua puluh jilid, dengan satu jilid

36 Seyyed Vali Reza Nasr, (1995), Great Thinkers of the Eastern World, New York: State University Press, hlm. 499.

37 Ali Naqi Baqirshani, (2000), "DasarDasar Nilai Moral Studi Komparatif atas PandanganAllamah Thabathaba'i dan Ayatullah Muthahhari", dalam Al-Huda: Jurnal Kajian ilmuilmu Islam, Vol 1, No. 2, hlm. 105. sebagai fahrasat, indeksnya. Proses penerbitan karya ini dilakukan secara berangsurangsur. Artinya, yang dicetak pertama adalah jilid pertamanya pada tahun 1375 H/1957 M. Dan penerbitannya secara keseluruhan dilakukan pada tahun 1392 H/1974 M. ${ }^{38}$ Al-Mizan adalah kata yang dipakai sebagai judul dari tafsir ini.Dipergunakannya term ini karena dalam tafsir ini banyak memuat pendapat para ulama tafsir, baik klasik maupun modern, dari Syi'ah atau Sunni.Semua pendapat ini yang dijadikan sebagai bahan "pertimbangan" Thabathaba'i, untuk memperkuat satu pendapat dengan lainnya, atau dengan pendapatnya sendiri, setelah merujuk kepada Alquran. ${ }^{39}$ Bahkan, tidak jarang, dari beberapa pendapat tersebut, ada yang menjadi bahan kritiknya.

Hawzah Qum menjadi tempat bagi Thabathaba'i dalam rangka mentransformasikan pengetahuannya dalam bidangbidang ilmu keislaman pada tahun hlm 398.

${ }^{38}$ Lihat Thabãthabã'i, Al-Mĩzan, jilid 20,

39 'Ali Awsiy, Thabathabã'i ...op.cit.,hlm 115. 
1325 H. Ilmu Tafsir menjadi salah satu cabang ilmu yang diajarkan Thabathaba'i kepada para mahasiswanya, dan menjadi salah satu mata kuliah yang menarik, bahkan, menjadi salah satu obyek diskusi Thabathaba'i yang melibatkan para sarjana dan mahasiswa, dengan kemampuan intelegensia di atas rata-rata, di lingkungan hawzah ${ }^{40}$ ilmiah Qum.

Sangat mungkin sekali bahwa selama diselenggarakannya kuliah-kuliah yang cerdas dalam materi tafsir, Thabathaba'i telah menyiapkan materinya ini dalam bentuk prosa yang padat namun indah. ${ }^{41}$ Sehingga, dari materi kuliah ini dipersiapkannya model kerangka penulisan dalam bentuk kitab.Kemungkinan ini bisa diterima.Sebab, di beberapa kesempatan Thabathaba'i telah berkali-kali memberikan kuliah tafsirnya yang meliputi seluruh kandungan Alquran kepada para mahasiswanya.Dari kerangka yang, pada awalnya, berbentuk

\footnotetext{
${ }^{40}$ Hamzah adalah kelompok orang yang duduk melingkari seorang syaikh untuk mendapatkan ilmu darinya.Istilah lebih dikenal di dunia Syi'ah.
} Introductionop.cit, him 12. prosa padat ini belakangan diterbitkan hanya dalam bentuk volume kecil.Yang kedua, adalah karya ini tidak "naik" ke percetakan secara menyeluruh, namun dicetak berangsur-angsur. Sebenarnya, keinginan Thabathaba'i untuk menulis suatu buku tafsir sudah muncul sejak awal kedatangannya ke Qum.Hal ini lebih banyak didasarkan pada beban moril yang dipikulnya sebagai seorang ulama, sekaligus intelektual.Karena, dalam pencermatannya, kondisi Hawzan Qum mengalami resesi keilmuan dan degradasi wacana pemikiran, terutama keilmuan Islam.Situasi ini lebih disebabkan adanya asumsi bahwa wacana dan pemikiran Islam tidak mampu lagi membendung pemikiran materialistik yang sudah menggejala di kalangan civitas akademika Hawzah Qum.Inilah yang menjadi salah satu dasar Thabathaba'i dalam menulis tafsirnya ini. Hal ini bisa dipahami dari ungkapannya:

"Ketika saya datang (pertama kali) dari Tabriz ke Qum, saya mempelajari dan melihat adanya pelbagai kebutuhan 
dalam diri masyarakat Islam, berikut pelbagai situasi yang melingkupi lembaga Qum ini. Pada akhirnya saya berkesimpulan bahwa lembaga tersebut membutuhkan satu tafsir Alquran untuk mendapatkan sebuah pemahaman yang lebih baik dan instruksi yang lebih efektif untuk sampai pada makna yang tersirat dalam teks yang paling penting dan paling tinggi kedudukannya di dalam Islam 42

Dengan keadaan demikian, Thabathaba'i memandang wacana rasional dan filosofis adalah satu kebutuhan besar untuk mengcounter paham materialisme yang berkembang pada masa itu.Di samping itu, usaha ini, bisa memberikan peluang bagi Hawzah Qum untuk mengelaborasikan prinsip-prinsip intelektual dan doktrinal ajaran Islam, yang

42 Teks Inggrisnya demikian: " When I came to Qumfrom Tabriz I tried to evaluate the requirements of the Islamic society as well as the conditions prevailing in the Hawzeh-ye 'Ilmiyyah of Qum. And after due consideration of the matter I came to the conclusion that the school was badly in need of a commentary of the Quran for a better understanding and more effective instruction of the sublime meanings of the purest of Allah Swt. Islamic texts and the highes of Allah Swt. Devine gifts" Abu Qasim Razzaqi, "An Introduction...op.cit., him 11-12. didasarakan pada argumen rasionalis, demi mempertahankan sikap dan kedudukan Islam.Dari posisi seperti ini Thabathaba'i merasa adalah kewajibannya untuk merealisasikan maksud tersebut, dan dengan pertologan Allah Swt., Thabathaba'i tidak saja mampu memenuhi kebutuhan pertama, bahkan keduanya.

Abu al-Qasim al-Razzaqi menginformasikan bahwa edisi pertama dari tafsir ini tertulis dalam bahasa Arab. Edisi ini diterbitkan di Iran, kemudian di Beirut. Sampai sekarang tafsir ini telah tersebar di beberapa universtas dan perpustakaan.Tidak sedikit perpustakaan umum maupun pribadi yang mengoleksi karya ini dalam edisi komplet.Kalau pun tidak, mereka mengoleksinya dalam beberapa edisi saja. ${ }^{43} \mathrm{Hal}$ itu menunjukkan bahwa tafsir ini telah diterima oleh masyarakat luas.

Dalam edisi Arab, yang merupakan teks asli tafsir ini, terdiri dua puluh volume.Setiap volume terdiri atas sekitar empat

${ }^{43}$ Lihat, ibid. 
ratus halaman dalam ukuran besar. Penerbitan tafsir ini dengan bahasa Arab dimaksudkan agar mereka yang tertarik membaca tafsir ini akan memperoleh pengetahuan memadai dari ajaran-ajaran yang dikandungnya. Beberapa murid Thabathaba'i, telah menerjemahkan karya ini ke dalam bahasa Parsi di bawah arahan dan bimbingan langsung guru mereka.Terjemahannya ke dalam bahasa Inggrisdikerjakan oleh Mawlana Sa'id Akhtar Ridwi, ${ }^{44}$ dan, sekarang, telah rampung semua volume yang ada. Setiap volume yang diterjemahkan ke bahasa Parsi dibuat dalam dua volume.Dengan demikian jumlah seluruhnya, versi asli dan Persia, menjadi empat puluh volume.Aqa Sayyid Muhammad Baqir Musawi Hamadani 45 adalah orang yang diserahi tanggungjawab dan mandat dalam proyek penerjemahan tersebut.Tujuan penerjamahan ini agar pembaca memperoleh pemahaman yang utuh atas uraian dari tafsir ini.

${ }^{44}$ Lihat, ibid, hlm 12.

${ }^{45}$ Lihat, ibid.
Semua uraian dalam tafsir ini dituturkan dengan gaya bahasa yang hidup. Gaya penyampaian seperti ini merupakan "sorga" bagi mereka yang memang pada dasarnya merindukan suatu teks bisa mengantarkan mereka untuk mengetahui lebih dalam tentang pengetahuan Ilahiah. Terlebih lagi, seandainya karya ini sampai ke tangan para individu yang committed, serta para sarjana yang familiar dengan ungkapan gaya bahasa Alquran.

Kandungan tafsir ini tidak juga kosong dan kering dari dimensi spiritual, yang merupakan akar pemikiran penulisnya (tafsir) sendiri. Bagi mereka yang menekuni dan konsisten pada jalur seperti ini, tafsir ini bisa menjadi referensi alternatif, di samping karya-karya lainnya, dalam obyek yang sama. Atau, kurang lebih, tafsir ini bisa mendekatkan pembacanya pada pemahaman lebih lanjut atas obyek tersebut.Meskipun, harus diakui, tafsir ini bukanlah kitab yang secara khusus membahas materi tersebut, seperti karya lainnya yang secara khusus memperbincangkan dimensi 


\begin{tabular}{lrr}
\multicolumn{2}{l}{ spiritual.Walau } & demikian, \\
ungkapan-ungkapannya & dalam \\
dimensi & spiritual & ini \\
dituturkannya & dalam & bahasa \\
universal. & &
\end{tabular}

Salah satu fungsi dari eksistensi karya ini adalah untuk memberikan jawaban atas tuduhan miring yang ditujukan golongan lain kepada Syi'ah. Tuduhan tersebut menyatakan bahwa Syi'ah memiliki Alquran yang tidak seperti yang dimiliki $\begin{array}{lr}\text { kaum } \quad \text { Muslim } & \text { secara } \\ \text { umum. }{ }^{46} \text { Kelompok } & \text { Syi'ah }\end{array}$

${ }^{46}$ Dalam banyak literature Syi'ah tidak mudah menemukan pernyataan dari para ulama mereka yang menyatakan bahwa mereka telah mendistorsi, atau memiliki Alquran seperti yang dimiliki umat Islam secara umum Seperti halnya Sunni, kaum Syi'ah juga meyakini bahwa Alquran adalah kitab suci yang bebas dari segala macam kekurangan dan reduksi. Keyakinan tersebut didasarkan pada pernyataan Alquran sendiri Dengan tegas Alquran mengindikasikan bahwa sangat tidak mungkin Alquran, yang ada sekarang ini, di dalamnya terdapat reduksi dan distorsi atau tahrif Pernyataan Alquran tersebut diabadikan Allah Swt dalam salah satu firmanNya: "Sesungguhnya Kami-lah yang menurunkan Al-quran dan Kami pula benar-benar memeliharanya". (Q.S al-Hijr (15) : 9). Fakhru alDtn al-Razi ketika mengomentari ayat ini menyatakan, dalam tafsirnya Mafatih al-Ghayb, bahwa kata hifzh, dalam kalimat lahafizhin, menunjukkan bahwa Alquran terbebas dari tambahan, fabrikasi, dan kekurangan. Ayat ini, lanjut al-Razi, merupakan tantangan Allah Swt kepada manusia untuk membuat satu surah atau satu ayat, jika mereka meragukan akan eksistensi dan kemurnian Alquran Senada dengan al-Razi adalah al-Maraghi Dalam tafsirnya, Tafsir al-Maraghi, pengarang kita ini mengatakan bahwa siapa yang menyatakan bahwa Alquran memiliki kekurangan, reduksi dan distorsi adalah orang gila, majnun Lihat, mendistorsi dan mereduksi

keberadaan Alquran yang beredar

sekarang ini. ${ }^{47}$ Ada beberapa ulama

Syi'ah yang menyatakan dengan

tegas bahwa Syiah tidak pernah

melakukan pengurangan ayat

Alquran.Di antara mereka, seperti

Abu Ja'far Muhammad ibn 'Ali ibn

Babawayh al-Qummi, yang dikenal

dengan al-Syakh al-Shaduq (w.

381/991). ${ }^{48}$ Al-Fadhl ibn

Syadzan ${ }^{49}$ serta, tokoh sentral kita,

Ahmad Musthofa al-Maraghi, (t th ), Tafsir alMaraghi, Juz 24, Beirut: Dar al-Fikr, hlm 9.

47Ihsan Ilahi Dhahir mengupas secara tuntas hubungan Syt'ah dengan Alquran sejak abad-abad pertama hingga masa kontemporer Lihat, Ihsan Ilahi Dhahir, (1995), al-Syi'ah wa AlQur'an, Pakistan ldarah Tarjaman al-Sunnah Lihat pula bantahan Thabathaba'i akan hal ini, Thabathaba'i, Al-Qur'an op.cit., terutama hlm. 13-28.

${ }^{48}$ Dalam karyanya yang beijudul al-I 'tiqad, Babawayh berkata: "With respect to the Holy Al-Qur'an which Allah Almighty has revealed to His Prophet Muhammad Saw., we believe that this is that very Al-Qur 'an which is between the two covers and is in the possesion of the people, and that there is not anything more than this. Whoever charges us with believing in excess, has lied" Terjemahan bebasnya: "Dengan segala hormat, Alquran yang diturunkan Allah Swt. kepada Nabi Saw.-Nya Muhammad Saw., kami meyakini bahwa inilah Alquran yang semua kaum Muslim berpegang dan bersandar padanya Tidak ada bentuk lain dari Alquran yang ada ini Dan siapa saja yang tidak mempercayai keyakinan kami ini, berarti dia telah berbohong". Cf. Muhammad Baqir Anshari, (1407), "Tahrif Al-Qur'an: A Study of Misconceptions Regarding Corruption of the Qur'anic Text, Jurnal Al-Tawhid, Vol IV, No 4, Shawwal-Dhu al-Hijjah, him 20.

49 Dalam kitabnya al-Idhdh, ia berkata: "But those who, by quoting such 
Thabathaba'i ${ }^{50}$ sendiri. Dalam

salah satu statemennya, ia menyatakan:

"...therefore, the Qur an is a living and eternal Reminder which will never die and Allah Swt. into oblivion. It is immune from any addition and less. It is immune from and secure against any alterations in form and style which could affect its character and role, that is, as, "Reminder of Allah which expresses divine truth and knowledge ". For this reason, the aforesaid verse indicates that the Divine Rook has always been and will continue to be guard against any multilaiion and alteration". 51

traditions, hold that the Qur anic text has been corrupted, are definitely making a mistake"Siapa saja yang mengatakan bahwa Alquran memiliki reduksi, dengan bersandar pada tradisi, maka nyata-nyata dia telah melakukan kesalahan" C f Muhammad Baqir Anshari, ibid., hlm. 19.

50 Untuk biografi kedua ulama Syi'ah di atas bisa dilihat dalam, Mirza Muhammad Baqir al-Musawi, ( $t$ th ), Raudhat al-Jannat fi Ahwal allflama wa al-Sadat, Qum: Mu'asasah al-Nasyar al-Isaiamiy Lihat juga, ' Abd al-Rahman 'Abd Allah al-Zar'i, (1983), Rijal al-Syi'ah fi AI-MJzan, Kuwait dar aI-Arqam, hlm 168-9 dan 126-131.

51Terjemahan bebasnya seperti, "... untuk itu, Alquran tetap akan menjadi Pengingat yang tidak pernah akan mati dan dilupakan orang la, Alquran, terbebas dari segala tambahan atau kekurangan ia bebas dan aman dari semua perubahan dalam bentuk dan gaya yang bisa berdampak pada karakter dan ciri khasnya Itu karena, Allah Swt sendiri yang menjadi Penjaga ayat-ayat-Nya. Dengan alasan

Lebih lanjut, di lain kesempatan dan tempat, penulis ini menambahkan:

52

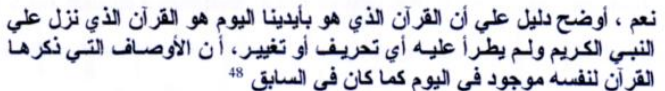

Dari

argumen

yang

dilontarkan oleh para ulama Syi'ah di atas dapat disimpulkan bahwa Syi'ah Imamiyah tidak pernah mengklaim memiliki Alquran tandingan dengan Alquran yang ada sekarang ini.Suara dan tuduhan yang ada, lebih banyak merupakan propaganda yang memiliki kecenderungan kuat ke arah politik ketimbang mempermasalahkan keabsahan dan validitas Alquran itu sendiri. Tuduhan seperti ini lebih bersifat mengeliminir peran serta dan

ini apa yang disebutkan oleh ayat tadi mengindikasikan bahwa Kitab ini akan selalu terjaga dari segala bentuk perubahan sampai kapan pun". Dikutip oleh Muhammad Baqir Anshari, "Tahrif Al-Quran...op.cit, hlm. 15.

52 Terjemahan bebasnya kurang lebih demikian "Benar, bukti sangat jelas bahwasanya Alquran yang ada di tangan kita sekarang ini adalah Alquran yang diturunkan (Allah Swt.) kepada Nabi Saw yang mulia, dan tidak ada didalamnya segala tahrif atau perubahan, serta semua sifat yang disebutkan oleh Alquran sendiri telah terdapat di dalamnya baik pada masa sekarang sebagaimana hal itu terdapat pada masa yang lalu " Lihat, Thabathaba'i , (1404), Al-Qur'an fiAl-lslam, Teheran: Markaz A'lam al-Dzikra, hlm 175 Lebih lanjut lihat pembahasan Thabathaba'i mengenai diskursus ini dalam, Al-MJzan, jilid 12, hlm 99-124, idem, Al-Mizan, jilid 16, hlm 214-5. 
ruang gerak Syfah, dalam setiap percaturan di bidang sosial, budaya dan keagamaan, setidaknya seperti yang diungkap oleh para ulamaSyi'ah sendiri. Hal ini menjadikan ruang gerak kelompok lain menjadi bebas, sebagaimana halnya aktivitas yang dijalani oleh Sunni, dalam bidang yang sama.

b. Sistematika dan Metode Penulisan

Al-Mizan, adalah karya tafsir yang memiliki metode berbeda dari kitab tafsir lainnya, klasik maupun kontemporer.Karya ini lahir dari tangan seorang yang tidak saja menguasai ilmu-ilmu Islam klasik.Namun dia juga sangat akrab dengan 'Irfan dan filsafat serta ilmu-ilmu kontemporer.Penulisnya juga telah bersentuhan, secara luas, dengan masyarakat modern, meskipun tidak secara langsung.

Karya ini berusaha, dengan segala kemampuan penulisnya, menyuguhkan jawaban yang cukup memuaskan atas setiap masalah dan permasalahan modern dengan tetap berpijak pada jalur yang baku; Alquran dan Sunnah. Sehingga, mau tidak mau penulisnya menggunakan metode modern dalam penulisannya.Di antara metode yang dipergunakan oleh penulis, tafsir, adalah mengembalikan semua inti permasalahan yang sedang dikaji dan dibahas kepada Alquran. Dengan ungkapan lain, penulisnya dalam menguraikan suatu ayat, yang berkaitan dengan suatu masalah, selalu merujuk terlebih dahulu kepada Alquran dan menggali makna ayat yang sedang dikaji dari ayat lain. Dengan begitu, pra-konsepsi dan teori yang ada hanya menjadi data sekunder.Bahkan, tidak jarang, data sekunder tersebut mendapat kritikan dari penulis tafsir ini.

Dalam pandangan Ibn Taymiyyah metode tafsir seperti ini merupakan "sebaik-baik metode penafasiran Alquran". ${ }^{33}$ Karena seorang mufasir dalam menafsirkan suatu ayat selalu merujuk kepada ayat lain dalam menafsirkan isi dari ayat tersebut. Namun, bilatafsiran ayat tersebut tidak ditemukan dalam satu ayat, maka ia akan ditafsirkan oleh ayat yang lain. Dan apa yang tidak disebutkan

53 Ibn Taymiyyah, (1392), Muqaddimah fi Usul al-Tafsĩr, tahkik 'Adnan Zarzur, Beirut: t $\mathrm{p}$ , hlm 93. 
dalam ayat tersebut, akan

diketengahkan di tempat lain.

Dalam ungkapan lain, cara yang paling ihtiyath, hati-hati, dalam menafsirkan ayat Alquran adalah dengan mencari pemahaman ayat tersebut dengan cara merujuk kepada ayat lain. Serta, berusaha untuk memahami dan mendalami ayat lain yang semakna dengan ayat sedang ditafsirkan tersebut.

Tidak jauh berbeda dengan yang diungkap oleh Dr. Muhammad Abdul Haleem, dalam bukunya Understanding the Qur'anic; Themes and Style. ${ }^{54}$ Menurutnya dalam memahami Alquran kaum Muslim, lebih khusus mufasir, menempuh dengan dua cara. Pertama, secara kontekstual, kedua, internal relationships atau hubungan ke dalam.Jika yang pertama, para mufasir menafsirkan ayat demi ayat sambil menyesuaikan pembahasannya dengan konteks 55 yang berkembang. Maka cara yang

54 Muhammad Abdul Haleem, (1999), Understanding the Qur'anic Themes and Style, New York: I.B Tauris Publisher, hlm 12.

${ }^{55}$ Taufik Adnan Amal dan Syamsurizal Panggabean mencoba mendiskusikan wacana moderl tafsir ini dalam buku mereka, (1989), Tafsir Kontekstual Al-Qur'an, Bandung: Mizan. kedua seperti yang tergambar

dalam

diktum,

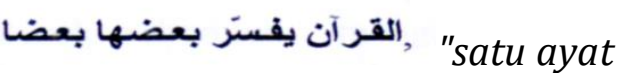

dalam Alquran salingmenafsirkan ayat lainnya Ungkapan senada juga pernah diutarakan oleh Ali bin Abi Thalib, "Sebagian Alquran menafsirkan sebagian yang lain. Sebagian menjadi saksi bagi bagian yang lain". 56

Dalam metode pertama, tidak jarang, para mufasir dalam menafsirkan satu ayat, terkesan memaksakan pemaknaan suatu ayat secara kontekstual.Sehingga ayat tersebut, hampir selalu, jauh dari pengertian yang dimaui oleh Alquran sendiri.Makna suci Alquran, dan kitab yang disucikan lainnya, sering dipaksakan pemaknaannya dengan mengikuti konteks yang berkembang. Akibatnya yang terjadi adalah bentuk apologi penafsirnyasendiri dalam menjawab masalah yang muncul. Posisi Alquran, tidak lebih, hanya menjadi legalisasi produk pemikiran mufasirnya. Dan lebih parah lagi, hal-hal yang berbau transenden dipaksa oleh

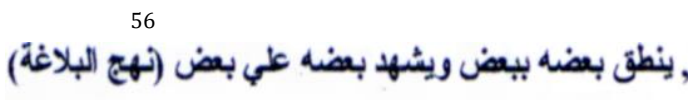

Lihat, Thabãthabã'i, Al-Mĩzãn, jilid 1, hlm 68. 
penafsirnya untuk dipahami secara material, imanen.Suatu usaha, yang, tidak saja berlebihan, bahkan sia-sia. ${ }^{57}$

Kenyataan seperti ini yang dicermati Thabathaba'i ketika pertama kali datang ke Qum, seperti telah disebutkan di atas.Karya tafsir yang ada, walaupun tidak semuanya demikian, hanya mengikuti kemauan penafsirnya dan terikat dengan premis serta postulat yang berkembang.Alquran tidak diberi kesempatan untuk mengungkapkan dirinya sendiri.Alquran, seakan-akan, terisolasi oleh pemikiran penafsirnya sendiri.Sehingga pengertian yang dikeluarkan oleh penafsirnya kehilangan maknanya yang paling fundamental, dan tidak jarang bukan seperti yang dimaui oleh teks.Terlebih teks suci seperti Alquran.

Diktum

di atas, mengindikasikan bahwa Alquran memiliki pengertian yang lebih dalam bila ia (Alquran) dibiarkan berbicara mengenai dirinya

57J.M.S. Baljon, (1968), Modem Muslim Koran Interpretation, Leiden E J Brill., hlm 88. sendiri. Alquran tidak 'dikebiri' dengan mengikuti konteks dan produk pemikiran penafsirnya.Terlebih lagi, bila si penafsir telah terkontaminasi oleh peradaban Barat dan aliran sains modern, yang telah kehilangan dimensi spiritualnya, dan, seringkah, berorientasi pada sekuler.

Alquran adalah "Respon Ilahiah terhadap kondisi umat manusia yang ditanamkan dalam qalb (kesadaran) Muhammad dengan latar belakang kondisi sosio-kulturo-historis dan logosfer bangsa Arab. ${ }^{58}$ Untuk itu, seharusnya Alquran dibiarkan berbicara sendiri mengenai dirinya.Alquran harus dipahami dari yang diungkapkan oleh dirinya sendiri.Bukan seperti yang dipahami, apalagi dimaui, oleh masing-masing orang, penafsir. ${ }^{59}$ Inilah yang dipakai oleh Thabathaba'i dalam menafsirkan setiap ayat dalam Kitab Suci iniMufassir kita ini membiarkan Alquran berbicara tentang dirinya sendiri, sebelum ia dikomentasi.

58Taufik Adnan Amal dan Syamsurizal Panggabean, Tafsir. .op.cit., hlm 42.

${ }^{59}$ Thabãthabã'i, Al-Our'ãn op.cit., hlm 14. 
Thabathaba'i mencari pengertian suatu ayat yang sedang ditafsirkan kepada ayat lain yang memiliki makna yang sebanding dan seirama dengannya.

Secara mujmal, sistematikan yang dipakai Thabathaba'i dalam karya tafsirnya ini, pada dasarnya, tidak jauh berbeda dengan sistematika yang dipergunakan oleh para mufassir pendahulunya dalam karya-karya tafsir mereka.'Ali al-Awsiy memetakan sistematika yang dipakai Thabathaba'i dalam menyusun karya tafsirnya ini. ${ }^{60}$ Di antaranya, yang bisa disebutkan di sini, adalah, pertama, Thabathaba'i, dalam membicarakan satu topik, membagi ayat-ayat dalam satu surah yang akan ditafsirkan menjadi kelompok tersendiri. Terlepas dari ayat tersebut masuk dalam kelompok satu surah atau tidak.Sehingga terkadang, dalam menafsirkan, Thabathaba'i memotong satu ayat ${ }^{61}$ atau 114-121.

60 Lihat 'Ali Awsiy, Thabãthahã'i.,hlm

\footnotetext{
61Lihat, Thabãthaba'i, Al-Mĩzãn, jilid 1,
} hlm. 121. sebagian ayat, ${ }^{62}$ bahkan, sebanyak duapuluh ayat. 63

Dalam beberapa hal, ketika menafsirkan, Thabathaba'i mengikuti sistem yang dilalui oleh mufasir terdahulu.Pada permulaan penafsiran di awal surah, Thabathaba'i telah menetapkan paradigma yang dipergunakan untuk memotret makna ayat tersebut. Dengan cara memadukan ayat-ayat tersebut dalam satu surah. Karena dalam pandangannya, juga para mufasir modern, bahwa dalam satu surah tidak hanya membicarakan satu topik saja. Namun ada bermacam masalah yang dipaparkan oleh ayat-ayat dalam surat tersebut ${ }^{64}$ Serta berbagai solusi untuk setiap masalah yang terkandung didalamnya. Begitu pula dalam memaparkan riwayat, dalam satu surah, terkadang Thabathaba'i menjelaskannya terlalu jauh. ${ }^{65}$ hlm 143.

62Lihat, Thabãthabã'i, Al-Mĩzãn, jilid 16,

63 Lihat, Thabathaba'i , Al-Mlzan, jilid, 2, hlm 227-230; jilid 10, hlm 145; jilid 14, hlm 257; jilid 15, hlm. 314.

${ }^{64}$ Lihat, Al-Mĩzãn, jilid I, hlm 16.

65 Lihat, Al-Mizan, jilid 10, hlm. 243, dan jilid 11, hlm. 206. 
Tidak jarang, Thabathaba'i menggunakan metode diskusi ketika menafsirkan suatu ayat, sambil membeberkan pendapat para ulama klasik pada ayat yang sedang dikaji. ${ }^{66}$ Selain itu, ketika mengutip pendapat mereka, para ulama, terutama dalam bahasa riwaiy, terkadang dia mengomentari riwayat tersebut, baik menguatkannya ${ }^{67}$ atau sebaliknya, ${ }^{68} \mathrm{atau}$ untuk memperkokoh pendapatnya sendiri, seperti dalam pembahasan tentang asbab al-nuzul 69 .

Thabathaba'i, dalam tafsirnya ini, seringkali mengangkat isu yang paling actual dan kontemporer yang juga menjadi isue Dunia Islam: yaitu mengangkat moral umat manusia, khususnya Islam, untuk melepaskan diri dari setiap bentuk paganisme. Tafsir bercorak seperti ini yang sangat dibutuhkan umat Islam di era informasi ini.Suatu era

66 Lihat, Al-Mĩzãn, jilid 12, hlm 364-366.

67 Lihat, Al-Mlzan, jilid 7, hlm. 13: dan jilid 20, hlm. 245.

${ }^{68}$ Lihat, AI-Mizan, jilid 2, hlm 378; jilid 9, hlm.14; jilid 12, hlm 79.

${ }^{69}$ Lihat, Al-Mizan, jilid 1, hlm 193. di mana umat Islam sepertinya telah kehilangan 'pegangan', karena terlalu bergantung pada hasil pemikiran sekularis.Akibatnya, Dunia Islam terlajur dicemari oleh bermacam idiologi asing yang seringkali mengganggu pikiran pemeluknya sendiri. ${ }^{70}$

$\begin{array}{cccc}\text { Satu } & \text { hal } & \text { yang } & \text { perlu } \\ \text { ditekankan } & \text { di } & \text { sini, } & \text { bahwa }\end{array}$
Thabathaba'i tidak sendirian, atau bukan satu-satunya tokoh, yang menafsirkan Alquran dengan gaya dan metode modern. Banyak penafsir modern yang sudah menerapkan metode tematik, maudhu'i, yang dipandang sebagai metode modern, dalam karya tafsir mereka.Suatu metode yang identik dengan diktum para ulama tafsir.Di antara mereka, untuk menyebut sekedar contohadalah Dr. 'Aisyah 'Abdurrahman, yang lebih dikenal dengan nama samarannya, Binthusy-Syathi'. ${ }^{71}$

70 'lffat Muhammad al-Syarqâwi, (1972), Illijahãl al-Tafsĩr Mishr wa al-'Ashr al-Hadĩs, Kairo: Mathba'ah al-Kaylani, hlm. 189.

${ }^{71}$ Untuk diskursus lebih jauh tentang metode tafsir Binthusy-Syathi', lihat, lssa J Boulatta, (1974), "Modern Qur'anic Exegesis: A Study of Bint al-Shati's Method", The Muslim World, Vol LXIV, No 4., hlm 103-113; Untuk terjemahannya, lihat. Jurnal Al-Hikmah, No. 3, Dzulhijjah, 1411- Rabiul Awwal 1412, hlm. 5-18. 
Menurut Binthusy-Syathi', penggunaan metode tematik dalam karya tafsirnya, adalah untuk "Membedakan antara metode penafsiran klasik dan modern, dan mengikuti diktum para mufassir klasik, "AlQur'anyufassiru ba'dhuha ba'dhan"72

c. Sumber Penafsiran Thabathaba'i

Sumber yang dipergunakan Thabathaba'i dalam karya tafsirnya ini ada dua; Alquran itu sendiri dan sumber lainnya.Sumber pertama dan utama merupakan sumber yang tidak bisa dilepaskan darinya. Karena ia merupakan fondasi dasar dalam menafsirkan setiap ayat. Dan ketika mengambil sumber kedua, penafsirnya selalu mendeskripsikan kepribadian tokoh yang dijadikan sebagai sumber. Sumber kedua ini berupa kitab-kitab tafsir,73 baik dari kalangan Syi'ah Imamiyah atau Sunni, hadis-hadis Nabi Saw., ${ }^{74}$

72 Binthu-Syathi, (1966), AI-Tafsir AlBayani li A!-Qur'an al-Karim, Juz I, Kairo: Dar alMa'arif,hlm.14.

$73 \quad$ 'Ali al-Awsiy, Thahãthabã'i...op.cit.,hlm 59-73.

${ }^{74}$ Ibid., hlm. 74-83. kamus bahasa Arab,75 buku-buku suci agama lain, al-kutub almuqaddasah $^{76} \quad$ sumber-sumber sejarah, ${ }^{77}$ Pengetahuan umum, mu'arif ammah $^{78}$ dan rasional; filsafat, ${ }^{79}$ koran serta majalah. ${ }^{80} \mathrm{Namun}$ di beberapa tempat, terkadang, Thabathaba'i tidak menyebutkan sumber rujukannya secara eksplisit, ketika mengutip sumber tersebut. Seperti sewaktu mengutip dari Ibn 'Abbas, Thabathaba'i berkata,wa nusiba ila Ibn 'Abbas wa mala ilayhi alJumhur. ${ }^{81} \mathrm{Di}$ sini, tampaknya, Thabathaba'i tidak menyebut secara eksplisit sumber kutipannya.

Selain Ibn 'Abbas, ada lagi kitab-kitab tafsir yang dijadikan sumber oleh Thabathaba'i. Di antaranya, karya Imam Abi Ja'far Muhammad ibn Jarir ibn Yazid ibn

75Ibid., hlm. 73-4.

76îbid, hlm 84.

${ }^{77}$ Ibid.

78Ibid., hlm 86.

${ }^{79}$ Ibid., hlm 87.

80ibid, hlm 88.

81

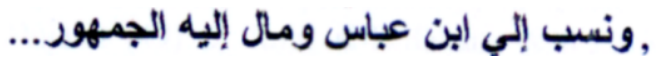

Lihat, Al-Mizãn, jilid 12, hlm. 157. 
Katsir al-Amili al-Thabari, Jami' alBayan ft Tafsir Al-Qur'an.Dari tafsir ini Thabathaba'i menukil qaul alshahabah, tabi'in, riwayat-riwayat tentang asbab al-nuzul.Misalnya, sewaktu menafsirkan ayat ke-44 dari surah al-Ma'idah, ${ }^{82}$ dan surah al-Nisa ayat $92 .{ }^{83} \mathrm{Kitab}$ tafsir Syfah yang dijadikan sumber oleh Thabathaba'i adalah Majma' alBayan, karya Abu al-Fadhl ibn alHasan al-Thabarsi.Tafsir ini merupakan referensi utama yang dipakaiThabathaba'i, setelah tafsir al-Tibyan karya al-Thusi dan Majma' al-Bayan karya Ibn Sa'id, di kalangan Syi'ah Imamiyah. ${ }^{84}$ Dari Majma' al-Bayan, Thabathaba'i banyak mengutip pendapat Thabarsi, khususnya ketika menguatkan pandanganpandangannya tentang makna suatu ayat. Seperti ketika sampai pada pembahasan mengenai masuknya orang taat ke dalam sorga, dalam surah Hud (11) ayat

82 Lihat Thabathaba i , Al-Mizan, jilid 5, hlm 375, Lihat pula Tafsir al-Thabari, juz $10 \mathrm{hlm}$ 338,343 .

${ }^{83}$ Lihat, Al-Mizan, jilid 5, hlm 44; Lihat pula Tafsir al-Thabari, juz 9, hlm.316.

84 Muhammad Baqir al-Khawansari, (1390), Raudhal al-Jannalfi Ahwal al-'Ulama wa al-Sadat, juz 5, Teheran: t p , hlm 357 Dikutip oleh Ali al-Awsiy, ...op.cit., hlm 63.
108, Thabathaba'i menguatkan pendapatnya dengan menukil pandangan Thabarsi. ${ }^{85}$

Kitab tafsir Sunni lain yang dijadikan oleh Thabathaba'i sebagai sumbernya adalah karya Fakhr al-Din ibn 'Umar ibn alHusain ibn al-Hasan al-Razi (w. $606 \mathrm{H})$, Mafatih al-Ghayb atau alTafslr al-Kablr.Banyak pendapat al-Razi yang dijadikan pendukung dalam menetapkan pendapatnya.Bahkan, terkadang, karya ini diposisikan sebagai partnerdiskusi, di satu sisi, serta di sisi lain, menjadi bahan kritikan Thabathaba'i.Terutama dalam topik-topik teologi yang mengandung dimensi filsafat. ${ }^{86}$

Selain karya al-Razi, Thabathaba'i juga menjadikan buah tangan $\mathrm{Abu}$ al-Qasim alHusain ibn Muhammad yang lebih dikenal dengan al-Ishfahani (w. $502 \mathrm{H}$ ), al-Mufradat fi Gharib AlQur'an, sebagai sumber rujukannya.Dari karya ini Thabathaba'i mencermati katakata Alquran yang termasuk dalam

${ }^{85}$ Lihat, Thabathaba'i, AI-Mizan, jilid 11, hlm, 36; Lihat juga Majma' al-Hayan, juz 3, hlm. 196.

${ }^{86}$ Lihat misalnya, Thabathaba'i, AlMizan, jilid 11, hlm 18-9. 
al-Mufradat fi Gharib.Misalnya

ketika menafsirkan ayat ke-29

surah al-A'raf (7), Thabathaba'i mengutip secara penuh uraian alIshfahani. ${ }^{87}$

Sedangkan hadis Nabi Saw. dan riwayat-riwayat para sahabat, dipakai juga oleh Thabathaba'i sebagai sumbernya, terutama ketika sampai pada pembahasan riwa'i. Adapun kitab-kitab hadis dan riwayat sahabat tersebut, di antaranya, al-Ihtijaj karya alThabarsi,al-Isti'ab fi Ma'r ifah alShahabah karya al-Qurthubi, serta Tahdzlb al-Tahdzib yang ditulis oleh Ibn Hajar al-'Asqalani, dan lainnya. ${ }^{88}$

Sedang sumber dari kamus, Thabathaba'i mempergunakan beberapa kamus standar.Seperti al-Shahhah oleh Ismail ibn Hamad al-Jauhari (w. 396 H), Lisan al'Arab karya Ibn Manzhur al-Mishri (w. 735 H).Karya Ahmad ibn

87 Lihat, Thabathaba'i , Al-Mizan, jilid 8, hlm. 74 Lihat pula Q S. Yunus (10): 4; Q S alRahman.

${ }^{88}$ Ali al-Awsiy menyebutkan sebanyak 99 buah buku hadis dan riwayat sahabat yang dijadikan sumber oleh Thabathaba'i Lihat 'Ali alAwsiy, Thabathaba'i op.cit., hlm 75-83. Untuk melihat kutipan kutipan Thabathaba'i dari berbagai sumber tersebut lihat, di antaranya, Thabathaba'i , Al-M'izan, jilid 3, hlm 83; jilid 4, hlm 381 dan 310.
Muhammad ibn 'Ali al-Muqri alFuyumi (w. $770 \mathrm{H}$ ), Mishbah alMunir.Dan Qamus al-Muhith oleh Muhammad ibn Ya'qub al-Fayruz al-Abadiy (w. 817 H). ${ }^{89}$ Dari semua kamus ini Thabathaba'i menguatkan pendapatnya, terutama tentang makna kata-kata yang sifatnya muradif ${ }^{90}$.

Kitab suci agama lain tidak luput juga di jadikan sumber rujukan oleh Thabathaba'i dalam karya tafsirnya ini. Kitab-kitab ini dipergunakannya ketika mengkomparasikannya dengan pandangan para ulama dalam memahami satu ayat.Namun, tidak jarang kitab-kitabini juga menjadi bahan kritikannya. ${ }^{91}$ Di antara kitab tersebut, adalah Injil, 92 Austa, kitab suci agama Majusi, ${ }^{93}$ 74-5.

89'Ali Awsiy, Thabathabã 'i ...op.cit., hlm.

90Untuk kutipan Thabathaba'i dari kamus, lihat misalnya, Al-Mizan, jilid 5, hlm 227, jilid 8, hlm 176, jilid 11, hlm.309, jilid 13, hlm. 309 , jilid 14 , hlm 43 , dan jilid 11 , hlm 50, lihat O.S. Hud (11), 113.

91Thabãthabã'i, Al-Mĩzãn, jilid, 6, hlm 178-8.

92Thabathaba'i , AI-Mizan, jilid, 3, hlm 284, 300, 308, 312, 315, 386; jilid 5, hlm 248, 253; jilid 6, hlm 70, 224.

93 Thabathaba'i, Al-Mĩzãn, jilid, 10, hlm 259. 
Taurat, $^{94}$ dan kitab suci agama Budha, Weda ${ }^{95}$ serta buku yang dianggap suci lainnya. ${ }^{96}$

Selain itu, pemikiran filsafat, baik klasik maupun modern, menjadi pendukungnya di beberapa tempat.Dari beberapa pemikiran filsafat ini ada yang dijadikan alat legitimasi bagi pemikirannya, ada pula yang dibandingkan, dan, bahkan, tidak jarang yang dikritiknya. ${ }^{97} \mathrm{Di}$ antara karya filsafat yang dijadikan sumber tersebut adalah, Ushul alFalsafah, yang ditulis sendiri olehnya. ${ }^{98}$

Buku-buku sejarah, dari klasik sampai modern, baik yang ditulis oleh Syi'ah maupun Sunni, tidak luput dari pengamatan Thabathaba'i, dan dijadikan sebagai sumber penafsirannya.Terlebih ketika menerangkan bahasan

94Thabathaba'i, Al-Mizan jilid lt hlm 140, jilid 5, hlm.223, 300; jilid 14, hlm 63.

95Thabathaba i, Al-Mlzan, jilid 10, hlm 291 dan jilid 13, hlm 379. hlm 84.

96'Ali al-Awsiy, Thabãthaba'i..... op.cit.,

97'Lihat, Thabãthaba'i, Al-Mĩzãn jilid 1, him. 52-4.

98Thabathabã'i, Al-Mĩzan, jilid 5, hlm. 263.
sejarah.Demikian pula buku-buku umum lainnya, seperti, fikih, usul fikih, teologi, filsafat, baik yang ditulis langsung olehtokohnya atau dalam bentuk komentarkomentar. Tidak ketinggalan juga majalah dan koran. ${ }^{99}$

Walhasil, Thabathaba'i memanfaatkan semua sumber yang bisa mendukung pendapatnya atau menjadi obyek kritikannya dalam karya tafsir ini.Namun begitu, dia selalu konsisten untuk tetap berada di jalur yang telah ditetapkan sebagai metodologinya dalam penafsiran.Sehingga, walau begitu banyak referensi yang ada tidak sampai mengaburkan atau menghilangkan metode yang ada.

Sehingga, tafsir ini bisa dijadikan contoh, sebagai kitab tafsir ideal. Karena di dalamnya akan ditemukan semua cabang ilmu yang "hilang" dalam genggaman kaum Muslim. Karya tafsir bisa disebut sebagai kitab ilmiah, seni, filsafat, sastra, historis, riwa'isosiologi, dan yang

${ }^{99}$ Ali Awsiy,ibid., hlm. 84-89. 
pasti tafsir Alquran dengan Alquran. ${ }^{100}$

\section{Penutup}

Thabathaba i, tidak seperti tokoh Iran lainnya, adalah tokoh yang dikenal pada waktu belakangan.Tokoh kita ini tidak seterkenal Imam Khomeini, tokoh spiritual Iran Iran yang memimpin revolusi Iran.Namun, dia tetap digolongkan sebagai ulama terkemuka Iran abad modern, dan sebagai figure yang kharismatik serta penuh wibawa. Walaupun dia tumbuh dan berkembang dari keluarga yang kurang beruntung secara ekonomis, namun hal itu tidak menghalangi dirinya untuk berkarya dan berkhidmat kepada sejumlah besar muridnya, di Tabriz dan Qum.Konsistensi hidup seperti ini, sangat mungkin, merupakan hasil tempaan kehidupan 'Irfan yang dijalaninya sejak masa belajarnya di Najaf hingga masa memasuki kehidupan dewasanya.

Al-Mizan fi Tafsir al-Quran merupakan karya Thabathaba'i yang paling fenomenal, dari semua tulisan yang pernah dihasilkannya.Karya tafsir ini, pada kenyataannya, tidak bisa dilepaskan dari pemikiran penulisnya

100 Demikian disampaikan oleh 'Ali alAwsiy ketika mengakhiri risalahnya Lihat, Ali alAwsiy, ibid , hlm. 267. yang bercorak filosofis.Karena, sebagaimana telah diketahui, filsafat merupakan salah satu cabang ilmu yang tidak pernah mati di kalangan Syiah, dan selalu mengalami perkembangan hingga sekarang ini.

\section{Daftar Pustaka}

Jalaluddin Rakhmat, Tafsir Sufi alFatihah: Muqaddimah, Bandung: Remaja Rosda Karya.

Moojen Moomen, An Introduction to Syiah Islam: The History of Twelver Shi'ism, United States: Yale University Press

Murtadah Muthahhari dalam Thabathaba'I, (1995), Shi'I, Manila: al-Hidaya.

Lihat misalnya Abu al-Qasim Razzaqi, (1406), "an introduction to almizan", dalam al-tawhid, Vol. III, No. 2, Rabi` al-Tsani-Jumada alTsani

M Th. Houtsman, et al, (Eds,), (1987), First Encyclopaedia of Islam, Vol VI, Leiden: E J Brill.

, "Pengantar Dr Husain Mahfudz", dalam al-Kulayni, (1375), Ushul al-Kafi, Jilid I, Iran Mathba'ah Haydar

Barzak Thahrani, (1370), Thabaqat A'lam al-Syi'ah, Jilid I, Naiaf: alMathba'ah al-'Ilmiyah,

Haidar Baqir, (peny), S H Nasr, "Tentang Penulis", dalam Thabathaba'i, (1993), Hikmah Islam.Cet IV, teri Bandung Mizan 
Lihat Sayyid Hosen Nasr, "Sang Alim dari Tabriz", dalam Thabathaba'i , (1993), Menyingkap Rahasia AlQur'an, terj A Malik Madaniy dan Hamim Ilyas, Bandung Mizan

al-Thahrani, (1375), l'habaqat A' lam alSyi'ah, Jilid 1, Najaf: al-Mathba'ah al-'llmiyah

M M Syarif, (ed), A History op. cit., Vol I, hlm. 480-506, Juga lihat Shams lnati, "Ibn 'Sina", dalam S H Nasr dan Oliver Leaman, (Eds ), (1996), History of Islamic Philosophy, Part I, London \& New York Routledge.

Fazlur Rahman, (1975), The Philosophy of Mulia Sadra (Sadr al-Din alSyirazi), New York: State University Press, S H. Nasr, "Sadr al-Din al-Sylrazi dalam M M Syarif, (ed ), A History.

Umar Ridha Kahalah, (1957), Mu 'jam al-Mu'allifin, Jilid 3, Damaskus: Mathba'ah al-Tarqi

Seyyed Vali Reza Nasr, (1995), Great Thinkers of the Eastern World, New York: State University Press.

Ali Naqi Baqirshani, (2000), "DasarDasar Nilai Moral Studi Komparatif atas PandanganAllamah Thabathaba'i dan Ayatullah Muthahhari", dalam Al-Huda: Jurnal Kajian ilmu-ilmu Islam, Vol 1, No. 2.

Ahmad Musthofa al-Maraghi, ( $t$ th ), Tafsir al-Maraghi, Juz 24, Beirut: Dar al-Fikr.

Cf. Muhammad Baqir Anshari, (1407), "Tahrif Al-Qur'an: A Study of Misconceptions Regarding
Corruption of the Qur'anic Text, Jurnal Al-Tawhid, Vol IV, No 4, Shawwal-Dhu al-Hijjah.

Abd al-Rahman 'Abd Allah al-Zar'i, (1983), Rijal al-Syi'ah fi AIMJzan, Kuwait dar aI-Arqam.

Ibn Taymiyyah, (1392), Muqaddimah fi Usul al-Tafsĩr, tahkik 'Adnan Zarzur, Beirut: t p.

Muhammad Abdul Haleem, (1999), Understanding the Qur'anic Themes and Style, New York: I.B Tauris Publisher.

Taufik Adnan Amal dan Syamsurizal Panggabean mencoba mendiskusikan wacana moderl tafsir ini dalam buku mereka, (1989), Tafsir Kontekstual AlQur'an, Bandung: Mizan.

J.M.S. Baljon, (1968), Modem Muslim Koran Interpretation, Leiden E J Brill.

lffat Muhammad al-Syarqâwi, (1972), Illijahãl al-Tafsĩr Mishr wa al'Ashr al-Hadĩs, Kairo: Mathba'ah al-Kaylani.

Issa J Boulatta, (1974), "Modern Qur'anic Exegesis: A Study of Bint al-Shati's Method", The Muslim World, Vol LXIV, No 4., hlm 103-113; Untuk terjemahannya, lihat.Jurnal AlHikmah, No. 3, Dzulhijjah, 1411Rabiul Awwal 1412.

Binthu-Syathi, (1966), AI-Tafsir AlBayani li A!-Qur'an al-Karim, Juz I, Kairo: Dar al-Ma'arif.

Muhammad Baqir al-Khawansari, (1390), Raudhal al-Jannalfi Ahwal al-'Ulama wa al-Sadat, juz 5, Teheran: $\mathrm{t} p$. 